\title{
Tetracycline resistance phenotypes and genotypes of coagulase-negative staphylococcal isolates from bubaline mastitis in Egypt
}

\author{
K. A. Abd El-Razik ${ }^{1}$ A. A. Arafa², R. H. Hedia² and E. S. Ibrahim²
}

1. Department of Animal Reproduction, Veterinary Division, National Research Center, Dokki, Giza, Egypt; 2 . Department of Microbiology and Immunology, Veterinary Division, National Research Center, Dokki, Giza, Egypt.

Corresponding author: K. A. Abd El-Razik, e-mail: khaled707@hotmail.com

Co-author: AAA: dr.amanyahmed@yahoo.com,RHH: rihamhassan1950@yahoo.in, ESI: dr.eman911@yahoo.com Received: 21-01-2017, Accepted: 08-05-2017, Published online: 25-06-2017

doi: 10.14202/vetworld.2017.702-710 How to cite this article: El-Razik KAA, Arafa AA, Hedia RH, Ibrahim ES (2017) Tetracycline resistance phenotypes and genotypes of coagulase-negative staphylococcal isolates from bubaline mastitis in Egypt, Veterinary World, 10(6): 702-710.

\begin{abstract}
Aim: This study was devoted to elucidate the tetracycline resistance of coagulase-negative staphylococci (CNS) derived from normal and subclinical mastitic (SCM) buffaloes' milk in Egypt.

Materials and Methods: A total of 81 milk samples from 46 normal buffalo milk samples and 35 SCM buffalo milk samples at private dairy farms of Egypt were used in this study. CNS were identified using phenotypic and molecular methods (polymerase chain reaction [PCR]). CNS isolates were tested for tetracycline resistance using routine methods and multiplex PCR targeting tetracycline (tet) resistance genes followed by sequencing of positive PCR products and phylogenetic analysis.

Results: Isolation and identification of 28 (34.5\%) CNS from normal and SCM buffaloes' milk, namely, Staphylococcus intermedius (39.2\%), Staphylococcus xylosus (25.0\%), Staphylococcus epidermidis (10.7\%), Staphylococcus hominis (10.7\%), and 3.5\% to each of Staphylococcus sciuri, Staphylococcus hyicus, Staphylococcus lugdunensis, and Staphylococcus simulans. Using nested PCR, all the $28 \mathrm{CNS}$ isolates revealed positive for 16srRNA gene specific for genus staphylococci and negative for thermonuclease (nuc) gene specific for Staphylococcus aureus species. The presence of tetracycline resistance-encoding genes (tet $\mathrm{K}$, tet $\mathrm{L}$, tet $\mathrm{M}$, and tet $\mathrm{O}$ ) was detected by multiplex PCR. All isolates were negative for tet $\mathrm{L}$, $\mathrm{M}$, and $\mathrm{O}$ genes while $14(50 \%) \mathrm{CNS}$ isolates were positive for tetK gene, namely, S. lugdunensis (100\%), S. hominis (100\%), S. epidermidis (66.6\%), S. intermedius (45.4\%), and S. xylosus (42.8\%). Nucleotide sequencing of tetK gene followed by phylogenetic analysis showed the high homology between our CNS isolates genes of tetracycline resistance with $S$. aureus isolates including Egyptian ones. This proves the transfer of the tetracycline resistance encoding genes between coagulase-negative and coagulase positive Staphylococcus spp.

Conclusion: CNS isolates have distinguishingly high resistance to tetracycline. Abundant tetracycline usage for mastitis treatment leads to the spread of genetic resistance mechanisms inside CNS strains and among all Staphylococcus spp. Consequently, tetracycline is not effective anymore.
\end{abstract}

Keywords: buffaloes, coagulase-negative staphylococci, mastitis, tetracycline resistance, tetK gene.

\section{Introduction}

Staphylococci are Gram-positive cocci-shaped bacteria that divided into coagulase-positive staphylococci and coagulase-negative staphylococci (CNS) based on the ability to coagulate rabbit plasma. CNS is characterized as non-Staphylococcus aureus staphylococci and considered as opportunistic mastitis pathogens. CNS has been generally viewed as minor pathogens. However, their significance has expanded in light of the fact that they have turned into the most frequently isolated group of species from bovine milk in numerous regions around the world and are regarded as emerging mastitis pathogens [1,2]. CNS usually causes subclinical mastitis (SCM), affects the quality of milk thus causing economic losses [3].

Copyright: El-Razik, et al. Open Access. This article is distributed under the terms of the Creative Commons Attribution 4.0 International License (http://creativecommons.org/licenses/ by/4.0/), which permits unrestricted use, distribution, and reproduction in any medium, provided you give appropriate credit to the original author(s) and the source, provide a link to the Creative Commons license, and indicate if changes were made. The Creative Commons Public Domain Dedication waiver (http:// creativecommons.org/publicdomain/zero/1.0/) applies to the data made available in this article, unless otherwise stated.
Antibiotic-resistant bacterial strains developed because of the boundless utilization of antibiotics on dairy farms and other food-producing animals [4] leading to severe public health issue that may be transmitted to human. Tetracycline-resistance genes (tet) appointed to classes $\mathrm{K}, \mathrm{L}, \mathrm{M}$, and $\mathrm{O}$ have been recognized in staphylococci of animal origin [5]. Three mechanisms were confirmed to play a part in resistance to tetracycline in staphylococci [6].

The resistance genes may exchange from staphylococci of animal origin to staphylococci that cause infections in humans, in this way compromising antimicrobial treatment [7]. CNS that colonizing the udder of buffaloes and cows may represent a reservoir of different antibiotic-resistant genes. Screening the antimicrobial resistance of bacteria in the dairy industry should be performed [8].

Therefore, the aim of this study is to determine the prevalence and tetracycline resistance profiles of CNS species isolated from clinically normal and SCM in buffaloes, molecular identification of CNS, detection of tetracycline resistance genes using multiplex polymerase chain reaction (PCR), DNA sequencing, and phylogenetic analysis. 


\section{Materials and Methods}

\section{Ethical approval}

The experiment was approved by Institutional Animal Ethics Committee.

\section{Sampling}

A total of 81 milk samples were aseptically collected from 46 normal buffalo milk samples and 35 SCM buffalo milk samples at private dairy farms surrounding Giza and El-Beheira governorates of Egypt. The animals were not treated with any antibiotic for at least 30 days before samples collection. Ten to fifteen $\mathrm{ml}$ of milk from each quarter was manually collected into separate sterile $25 \mathrm{ml}$ tubes. After gently suspending each sample, a collective milk sample representing all four quarters was created and quickly transported to the laboratory under chilled conditions and stored at $4^{\circ} \mathrm{C}$ until bacteriological and molecular examination.

\section{Isolation and identification of CNS $[9,10]$}

One $\mathrm{ml}$ out of a $10 \mathrm{ml}$ of each milk sample was mixed with $9 \mathrm{ml}$ of tryptic soy broth and then, incubated for $8-12 \mathrm{~h}$ at $37^{\circ} \mathrm{C}$. Ten microliters of milk were inoculated on tryptone soy agar plates supplemented with $5 \%$ bovine blood, which were incubated at $37^{\circ} \mathrm{C}$ for $18-24 \mathrm{~h}$. All isolates were identified as CNS based on colony morphology, Gram-staining, catalase reaction, and oxidative-fermentative testing. After confirmation of the genus Staphylococcus, the enzyme coagulase was characterized among all isolates. Coagulase-negative isolates were subjected to identification to the species level using the API Staph commercial identification system (API Staph ID32 test; bioMérieux, Marcy l'Etoile, France).

\section{Antibiotic resistance assay}

Tetracycline was selected for testing based on the licensing for mastitis treatment in cattle, use in human medicine and potential resistant determinant phenotypes $[11,12]$. Susceptibility of the isolates was determined against Tetracycline $(30 \mu \mathrm{g})$ and the confirmed CNS isolates were inoculated into Mueller-Hinton broth (Oxoid) and incubated overnight at $37^{\circ} \mathrm{C}$. The turbidity of the suspensions was adjusted to a $0.5 \mathrm{McF}$ arland standard and streaked onto Mueller-Hinton agar (Oxoid) plates. Antimicrobial disks were added on the plates and they were incubated aerobically at $35^{\circ} \mathrm{C}$ for $16-18 \mathrm{~h}$. The results were recorded as susceptible, intermediate, or resistant by measurement of the inhibition zone diameter according to the zone diameter interpretative standards of CLSI [13].

\section{Molecular confirmation of CNS identity}

A crude DNA preparation was made from the $28 \mathrm{CNS}$ isolates from milk samples. For extraction of DNA, bacterial pellets were re-suspended with $200 \mu 1$ phosphate-buffered saline. DNA was extracted from isolates using the DNA extraction Kits (GF-1, Vivantis Co., Malaysia) according to manufacturer's instructions. Duplex PCR was performed using two primer pairs $[14,15]$, one pair targeting the Staphylococcus genus-specific 16S rRNA gene (fragment of $228 \mathrm{bp}$ ) and the second primer pair targeting the $S$. aureus specific nuc gene (fragment of $279 \mathrm{bp}$ ). In each executed PCR run, a positive $S$. aureus control ( $S$. aureus DSM 20231 T), a positive CNS control (Staphylococcus epidermidis DSM 20044), and a negative control (water) were included for comparative analysis.

\section{PCR Screening of the genetic determinants of tetra-} cycline resistance $[16,17]$

For PCR amplification reactions, a final volume of $50 \mu$ contained $5 \mu$ DNA templates; $25 \mu \mathrm{l}$ of 2X Taq Master Mix (Cat. No. PLMM01, Vivantis Co., Malaysia). The primer concentrations were optimized for each multiplexed primer as follows: tet $(\mathrm{K})$ $1.25 \mu \mathrm{M}$, tet $(\mathrm{L}) 1.0 \mu \mathrm{M}$, tet $(\mathrm{M}) 0.5 \mu \mathrm{M}$, and $\operatorname{tet}(\mathrm{O})$ $1.25 \mu \mathrm{M}$. An initial denaturation hot start of $5 \mathrm{~min}$ at $94^{\circ} \mathrm{C}$ was followed by 35 cycles consisting of $30 \mathrm{~s}$ of denaturation at $94^{\circ} \mathrm{C}, 30 \mathrm{~s}$ of annealing at $51^{\circ} \mathrm{C}$ and $30 \mathrm{~s}$ of extension at $72^{\circ} \mathrm{C}$. Followed by a final extension of $10 \mathrm{~min}$ at $72^{\circ} \mathrm{C}$. Isolates putatively containing genes encoding for tetracycline resistance were identified by comparison with positive controls. Amplicons were visualized after electrophoresis on a $2 \%$ agarose gel containing red safe (Table-1) [16,17].

\section{DNA sequencing}

PCR products were sequenced in MACROGEN Company (Korea) on 3730XL sequencers (Applied Biosystem, USA). The accuracy of data was confirmed by two-directional sequencing with the forward and reverse primers used in PCR.

The nucleotide sequences obtained in this study were analyzed using the BioEdit 7.0.4.1 and Muscle (http://www.ebi.ac.uk/Tools/msa/muscle/) programs. The resulting sequences were aligned with tetK gene of reference sequences of Staphylococcus spp. using a neighbor-joining analysis of the aligned sequences

Table-1: Primers used for detection of tetracycline sensitivity

\begin{tabular}{|c|c|c|c|c|}
\hline Gene & Primers $\left(5^{\prime}->3^{\prime}\right)$ & Anneal. temp & Product & References \\
\hline $\operatorname{tet}(\mathrm{K})$ & $\begin{array}{l}\text { F; GTAGCGACAATAGGTAATAGT } \\
\text { R; GTAGTGACAATAAACCTCCTA }\end{array}$ & $51^{\circ} \mathrm{C}$ & $360 \mathrm{bp}$ & {$[16]$} \\
\hline $\operatorname{tet}(\mathrm{L})$ & $\begin{array}{l}\text { F; TCG TTA GCG TGC TGT CAT TC } \\
\text { R; GTA TCC CAC CAA TGT AGC CG }\end{array}$ & & 267 bp & [17] \\
\hline $\operatorname{tet}(\mathrm{M})$ & $\begin{array}{l}\text { F; GTG GAC AAA GGT ACA ACG AG } \\
\text { R; CGG TAA AGT TCG TCA CAC AC }\end{array}$ & & 406 bp & \\
\hline $\operatorname{tet}(0)$ & $\begin{array}{l}\text { F; AAC TTA GGC ATT CTG GCT CAC } \\
\text { R; TCC CAC TGT TCC ATA TCG TCA }\end{array}$ & & 515 bp & \\
\hline
\end{tabular}


implemented in the program CLC Sequence Viewer 6. The reliability of the trees was estimated by bootstrap confidence values [18], and 500 bootstrap replications were used.
The $\operatorname{tet}(\mathrm{k})$ of our isolates with sequences of 18 similar reference genes was used to construct the neighbor-joining tree (Figure-1) (by NCBI GenBank accession numbers) as shown in Table-2.

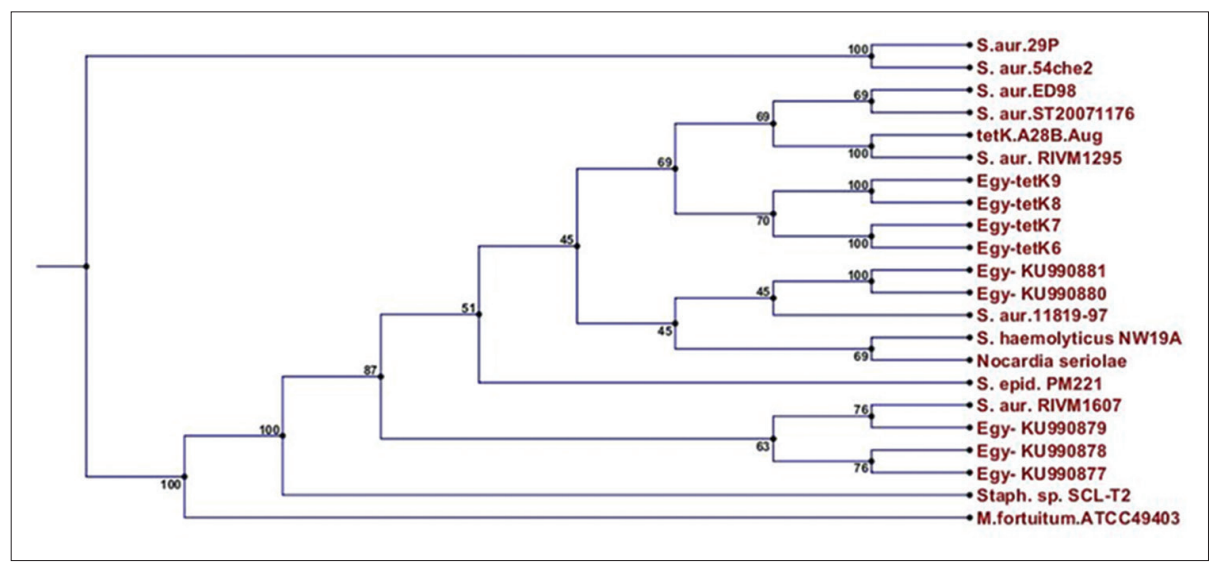

Figure-1: Phylogenetic relationship of selected strains of Staphylococcus spp. from different sources, representing the four distinct lineages, based on the tetK gene. The GenBank accession numbers of the isolates used are given.

Table-2: Details of CNS strains used in the present study with the available ones in GenBank.

\begin{tabular}{|c|c|c|c|c|c|}
\hline S.No. & Name & Strain & $\begin{array}{l}\text { Source of } \\
\text { isolation }\end{array}$ & Country & $\begin{array}{l}\text { Access } \\
\text { number }\end{array}$ \\
\hline 1 & Egy-tetK6 & Staphylococcus lugudensis & $\begin{array}{l}\text { Buffaloes } \\
\text { milk }\end{array}$ & Egypt & KX098498 \\
\hline 2 & Egy-tetK7 & Staphylococcus epidermidis & $\begin{array}{l}\text { Buffaloes } \\
\text { milk }\end{array}$ & Egypt & KX098499 \\
\hline 3 & Egy-tetK8 & Staphylococcus xylosus & $\begin{array}{l}\text { Buffaloes } \\
\text { milk }\end{array}$ & Egypt & KX098500 \\
\hline 4 & Egy-tetK9 & Staphylococcus hominis & $\begin{array}{l}\text { Buffaloes } \\
\text { milk }\end{array}$ & Egypt & KX098501 \\
\hline 5 & Egy-KU990877 & Staphylococcus aureus & Burger & Egypt & KU990877 \\
\hline 6 & Egy-KU990878 & Staphylococcus aureus & Minced Beef & Egypt & KU990878 \\
\hline 7 & Egy-KU990879 & Staphylococcus aureus & Bovine milk & Egypt & KU990879 \\
\hline 8 & Egy-KU990880 & Staphylococcus aureus & Minced Beef & Egypt & KU990880 \\
\hline 9 & Egy-KU990881 & Staphylococcus aureus & Bovine milk & Egypt & KU990881 \\
\hline 10 & $\begin{array}{l}\text { Staphylococcus haemolyticus } \\
\text { NW19A }\end{array}$ & $\begin{array}{l}\text { Staphylococcus haemolyticus } \\
\text { NW19A }\end{array}$ & Bovine milk & China & KM369884 \\
\hline 11 & $\begin{array}{l}\text { Staphylococcus epidermidis } \\
\text { PM221 }\end{array}$ & $\begin{array}{l}\text { Staphylococcus epidermidis } \\
\text { PM221 }\end{array}$ & & Finland & NZ_HG813246 \\
\hline 12 & Staphylococcus aureus RIVM1607 & Staphylococcus aureus RIVM1607 & Human & Netherlands & СР013619 \\
\hline 13 & Staphylococcus aureus 29P & Staphylococcus aureus 29P & $\begin{array}{l}\text { Pork samples } \\
\text { collected } \\
\text { from retail } \\
\text { meat shops }\end{array}$ & India & KP658722 \\
\hline 14 & Staphylococcus aureus 54 Che 2 & Staphylococcus aureus 54 Che 2 & $\begin{array}{l}\text { Chevon meat } \\
\text { sample from } \\
\text { retail shop }\end{array}$ & India & KP886833 \\
\hline 15 & Staphylococcus aureus ED98 & Staphylococcus aureus ED98 & Human & UK & СР001784 \\
\hline 16 & $\begin{array}{l}\text { Staphylococcus aureus } \\
\text { ST20071176 }\end{array}$ & $\begin{array}{l}\text { Staphylococcus aureus } \\
\text { ST20071176 }\end{array}$ & Human & Tunisia & KM281802 \\
\hline 17 & Staphylococcus aureus RIVM1295 & $\begin{array}{l}\text { Staphylococcus aureus } \\
\text { RIVM1295 }\end{array}$ & Human & Netherlands & СР013616 \\
\hline 18 & tetK_A28B_Aug & Uncultured bacterium & $\begin{array}{l}\text { River benthic } \\
\text { biofilm }\end{array}$ & New Zealand & KM668512 \\
\hline 19 & Staphylococcus aureus 11819-97 & Staphylococcus aureus 819-97 & $\begin{array}{l}\text { Human } \\
\text { (abscess } \\
\text { on lower } \\
\text { extremity) }\end{array}$ & Denmark & СР003193 \\
\hline 20 & Staphylococcus sp. SCL-T2 & Staphylococcus spp. & & New Zealand & JN801166 \\
\hline 21 & Nocardia seriolae CN101 & Nocardia seriolae CN101 & $\begin{array}{l}\text { Seriola } \\
\text { dumerili fish }\end{array}$ & Japan & AB513133 \\
\hline 22 & $\begin{array}{l}\text { Mycobacterium fortuitum } \\
\text { ATCC } 49403\end{array}$ & $\begin{array}{l}\text { Mycobacterium fortuitum } \\
\text { ATCC } 49403\end{array}$ & & Korea & AF057465 \\
\hline
\end{tabular}

CNS=Coagulase-negative staphylococci

Veterinary World, EISSN: 2231-0916 
Nucleotide sequence accession numbers

Four sequences PCR samples (Egy-tetK 6-9) used in this study have been deposited in the GenBank database under accession no: KX098498, KX098499, KX098500, and KX098501, respectively.

\section{Results}

\section{Bacterial isolation and identification}

Our results confirmed the isolation and identification of $28(34.5 \%)$ coagulase-negative staphylococci (CNS) from normal and SCM buffaloes' milk (Table-3). Most of the isolates were Staphylococcus intermedius (39.2\%) and Staphylococcus xylosus (25\%), followed by Staphylococcus hominis and S. epidermidis $(10.7 \%$ each), while the lowest incidences were for Staphylococcus lugdunensis, Staphylococcus hyicus, Staphylococcus simulans and Staphylococcus sciuri (3.5\% each) as shown in Table-3.

\section{Phenotypic distribution of tetracycline resistance in CNS isolates}

The in vitro sensitivity of the $28 \mathrm{CNS}$ isolates for tetracycline revealed an incidence of resistance of $42.8 \%(12 / 28)$ in the CNS isolates as shown in Table-4, where $100 \%$ of $S$. lugdunensis and S. hominis and $66.6 \%, 42.8 \%$, and $27.2 \%$ of $S$. epidermidis, S. xylosus, and S. intermedius isolates, respectively, were resistant to tetracycline. On the contrary, all the $S$. hyicus, S. simulans, and S. sciuri isolates were sensitive to tetracycline antibiotic.

\section{Nested PCR targeting 16S rRNA gene and nuc gene of 28 CNS isolates}

The results revealed a positive amplification of $228 \mathrm{bp}$ fragment of primer specific for 16s rRNA gene (specific for genus Staphylococcus) and a negative amplification of $n u c$ gene at $279 \mathrm{bp}$ (S. aureus species specific) for all 28 isolates of the genus staphylococci examined.

\section{Results of multiplex PCR for the genes encoding tetracycline}

Using multiplex PCR, all isolates were negative for tet $\mathrm{L}, \mathrm{M}$, and $\mathrm{O}$ genes encoding tetracycline while tet $\mathrm{K}$ gene was detected in $14 \mathrm{CNS}$ isolates (Figure-2) with an incidence of $50 \%$. In detail, the tetK gene was detected in all $S$. lugdunensis and $S$. hominis isolates with an incidence of $100 \%$ while it was detected in S. epidermidis, $S$. intermedius, and S. xylosus with an incidence of $66.6 \%, 45.4 \%, 42.8 \%$, respectively, as shown in Table-4. On the contrary, all the S. hyicus, S. simulans, and S. sciuri isolates were negative to for tetK gene.

\section{Association of antimicrobial resistance phenotype with resistance-associated genes}

Analysis of the presence of the tet $\mathrm{K}$ genes in the $28 \mathrm{CNS}$ isolates with antimicrobial resistance patterns was conducted as shown in Table-4. A detailed analysis displayed associations of resistance/susceptibility phenotypes with potential resistance genes except in two isolates where an intermediate resistance

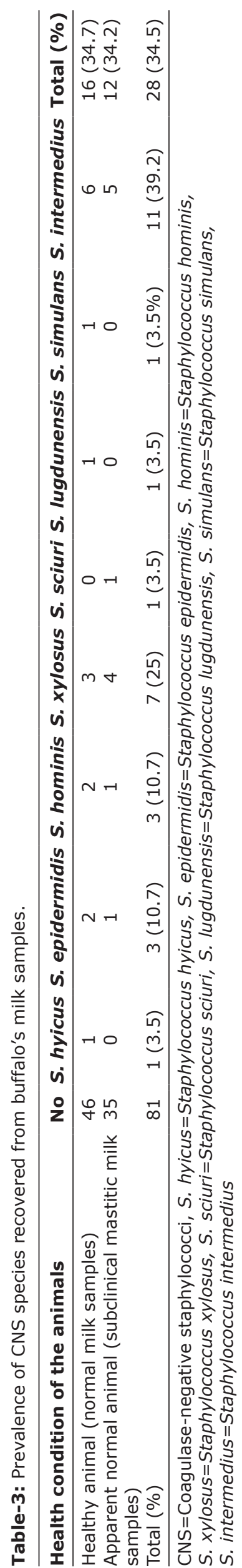


Table-4: Distribution of tetracycline resistance gene combinations in the 7 different CNS species constituting the 28 CNS isolates from buffalo milk samples.

\begin{tabular}{lccc}
\hline $\begin{array}{l}\text { Staphylococcus species identified } \\
\text { by API }\end{array}$ & No of isolates & $\begin{array}{c}\text { Tetracycline resistance } \\
\text { assay }\end{array}$ & $\begin{array}{c}\text { Antibiotic resistance } \\
\text { gene (tetK) }\end{array}$ \\
\hline S. intermedius & 3 & $\mathrm{R}$ & + \\
S. intermedius & 5 & $\mathrm{~S}$ & - \\
S. intermedius & 1 & $\mathrm{~S}$ & + \\
S. intermedius & 1 & $\mathrm{I}$ & + \\
S. intermedius & 1 & $\mathrm{I}$ & - \\
S. xylosus & 3 & $\mathrm{R}$ & + \\
S. xylosus & 4 & $\mathrm{~S}$ & - \\
S. epidermidis & 2 & $\mathrm{R}$ & + \\
S. epidermidis & 1 & $\mathrm{~S}$ & - \\
S. hominis & 3 & $\mathrm{R}$ & + \\
S. lugdunensis & 1 & $\mathrm{R}$ & + \\
S. hyicus & 1 & $\mathrm{~S}$ & - \\
S. simulans & 1 & $\mathrm{~S}$ & - \\
S. sciuri & 1 & $\mathrm{~S}$ & - \\
\hline
\end{tabular}

$\mathrm{R}=$ Resistant, I=Intermediate, S: Susceptible, CNS=Coagulase-negative staphylococci, S. hyicus=Staphylococcus hyicus,

S. epidermidis=Staphylococcus epidermidis, S. hominis=Staphylococcus hominis, S. $x y l o s u s=S t a p h y l o c o c c u s ~ x y l o s u s$,

S. sciuri=Staphylococcus sciuri, S. Iugdunensis=Staphylococcus lugdunensis, S. simulans=Staphylococcus simulans,

S. intermedius $=$ Staphylococcus intermedius

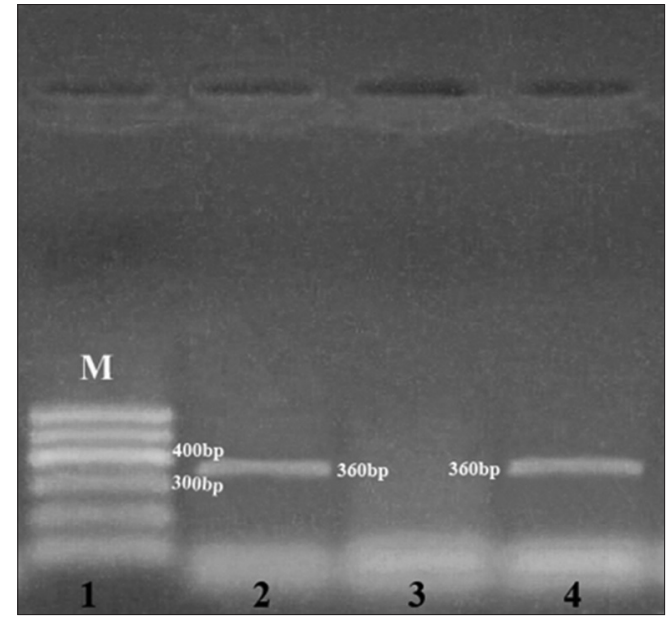

Figure-2: Agarose gel electrophoresis using polymerase chain reaction with amplification of the 360-bp fragment for the tetracycline resistance (tetK) gene performed with specific primer: Lane 1, 100-bp DNA ladder; lane 2, positive control: Lane 3, negative control, lane 4, positive amplification of the $360 \mathrm{bp}$ fragment of the tetK gene from coagulase-negative staphylococci species.

phenotype $(1 / 11,9.09 \%)$ and a susceptible phenotype $(1 / 11,9.09 \%)$ harbored the tetK gene.

\section{Phylogenetic analysis}

The phylogenetic tree showed that all tet $(\mathrm{K})$ genes of tetracycline resistance (Egy-tetK 6-9) were gathered with their similar reference genes sequences and formed two groups, which indicating high level of identity between the local isolates genes and their corresponding reference sequences in the GenBank (Figure-3).

\section{Sequence analysis of $\operatorname{tet}(K)$ gene}

The sequences of tet $(\mathrm{K})$ genes of CNS obtained in the current study were compared with the sequences of tet $(\mathrm{K})$ genes retrieved from GenBank. Similarity between obtained sequences with those from GenBank was 69.00 to $100 \%$. This showed that the sequenced part of $\operatorname{tet}(\mathrm{K})$ gene was from a highly conservative region (Figure-3). The only change was the (A) nucleotide number 196 was substituted with (T) base in the Egyptian $S$. aureus isolates (Ku-990877-79) and RIVM1607. Phylogenetic tree of the tetK gene sequences was inferred using the maximum likelihood method based on Tamura-Nei model (24). Based on generated phylogenetic tree, four CNS isolates examined in the present study grouped in seven distinct clusters (Figure-1). Phylogenetic analysis confirmed the results of PCR for the four CNS isolates.

\section{Discussion}

Coagulase-negative staphylococci have been considered the most common mastitis causing agents in several countries [19]. They mostly cause SCM (Pyörälä and Taponen, 2009). CNS mastitis responds much better to antimicrobial treatment than $S$. aureus mastitis but it is realized that resistance to various antimicrobials is more prevalent in CNS than in S. aureus [20] as they can easily develop multi-resistance.

Our results confirmed the isolation and identification of 28 (34.5\%) CNS from normal and SCM buffaloes' milk (Table-3). Most of the isolates were S. intermedius $(39.2 \%)$ and S. xylosus $(25 \%)$. This was in agreement with that of Osman et al. [21], with an incidence of S. intermedius (31.8\%) and S. xylosus $(29.5 \%)$, respectively.

Moreover, this was also comparable to that of El-Ashker et al. [22] that confirmed an isolation rate of $44.4 \%$ CNS with $S$. xylosus as the most prevalent CNS from buffalo's milk (75\%). Although S. xylosus is not known to cause mastitis, this, emphasizing previous studies that $S$. xylosus is an underestimated pathogenic CNS in bovine mastitis [3].

Not very many studies have examined contrasts in antimicrobial resistance among CNS species [10]. 


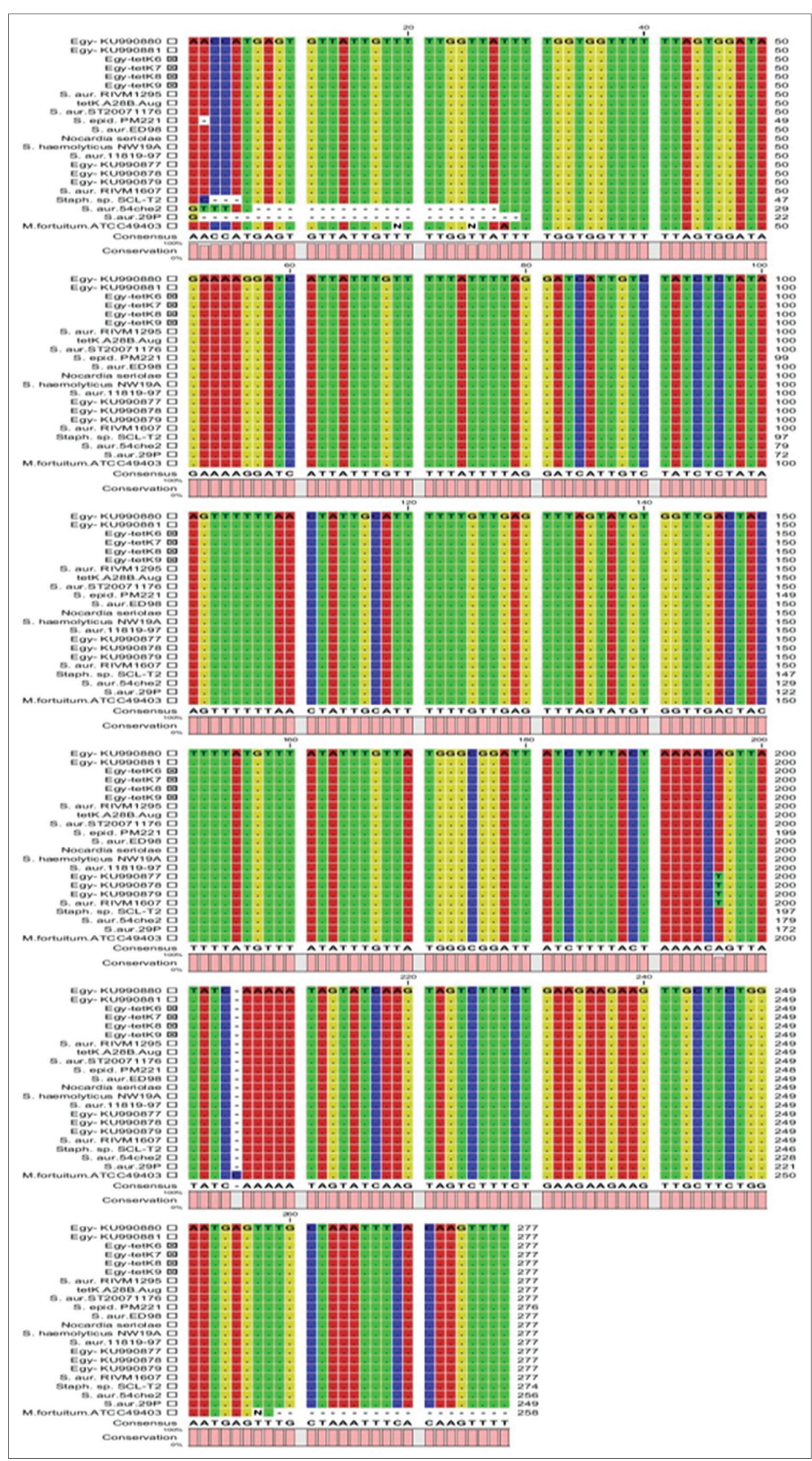

Figure-3: Multiple sequence alignment of coagulase-negative staphylococci (present study) isolated from buffaloes milk (Egy-tetK 6-9) and their corresponding reference sequences. Only variable sites are shown with different color. Dashes in the middle indicate gaps.

Distinguishing to species level would be critical in the event that it has effect on administration and treatment choices [23].
From the current study, the in vitro sensitivity of the $28 \mathrm{CNS}$ isolates against tetracycline revealed an incidence of resistance of $42.8 \%$ in the CNS isolates, 
where $100 \%$ of $S$. hominis and S. lugdunensis and $66.6 \%, 42.8 \%$ and $27.2 \%$ of S. epidermidis, S. xylosus and $S$. intermedius isolates, respectively, were resistant to tetracycline. On the contrary, all the $S$. hyicus, $S$. simulans and $S$. sciuri isolates were sensitive to tetracycline antibiotic. This was in agreement to that of Osman et al. [8] which revealed an incidence of tetracycline resistance of $25.5 \%$ in the CNS isolates, where the $75 \%$ of $S$. hominis, $100 \%$ of S. lugdunensis and $50 \%, 23 \%$ and $21.4 \%$ of S. epidermidis, S. xylosus and $S$. intermedius isolates, respectively, were resistant to tetracycline. The other isolates were typically sensitive to tetracycline as in our results.

Our results can be explained that, in most countries, tetracycline is routinely used to treat mastitis and in the water of the herd as a prophylactic measure aimed at reducing infections [24]. Widespread and continuous use of tetracycline leads to increase in resistance toward these antimicrobial agents [25].

Using PCR, positive amplification of 16srRNA gene fragment (specific for genus Staphylococcus) and a negative amplification of nuc fragment for all isolates ( $S$. aureus species specific). This proves that genotypic methods have higher specificity and sensitivity than other methods for discriminating among species, resulting in a better alternative for the routine identification of CNS isolates as reported by [26].

Tetracycline resistance determinants are broad among bacterial species and are regularly found in multi-drug resistant bacteria [27]. Resistance is frequently due to the obtaining of new genes connected with either conjugative plasmids or transposons [6]. Tetracycline is utilized for treatment of bovine mastitis [28]. Prolonged use may prompt to the emergence of tetracycline resistant Staphylococcus species which is a serious concern not only in animal health but also to human health because of the presence of tetracycline resistant genes which can be exchanged between staphylococcal species through horizontal exchange and these pathogens harboring resistant genes can be transferred to humans from bovines and vice versa $[29,30]$.

In the current study, we identified the tetracycline resistant genes tet $(\mathrm{K}),(\mathrm{L}),(\mathrm{M})$, and $(\mathrm{O})$ associated with a ribosomal protection mechanism and/or efflux mechanism [6]. The recognition of tetracycline resistance genes may be utilized as an extra genotypic marker for outbreak investigation and surveillance as reported by Duran et al. [16] and $\mathrm{Ng}$ et al. [17]. The used multiplex PCR has appeared to be a helpful technique to differentiate the mechanisms of tetracycline resistance.

Using multiplex PCR, all isolates were negative for tet $\mathrm{L}, \mathrm{M}$, and $\mathrm{O}$ genes while tet $\mathrm{K}$ gene was detected in $14(50 \%)$ CNS isolates. The tetK gene was detected in all $S$. lugdunensis and $S$. hominis isolates with an incidence of $100 \%$ while it was detected in S. epidermidis, S. intermedius, and S. xylosus with an incidence of $66.6 \%, 45.4 \%$, and $42.8 \%$, respectively.
This was parallel to that of Osman et al. [8] with the detection of the tetK gene in $28(29.8 \%)$ of CNS isolates (S. lugdunensis [100\%], S. hominis [75\%], $S$. epidermidis [40\%], S. xylosus, [28.6\%] and $S$. intermedius $[26.7 \%])$. In contrary to that El-Ashker et al., [22] using PCR for CNS isolated from buffaloes milk in Egypt. CNS isolates were positive to tet(M) gene and negative for $\operatorname{tet}(\mathrm{K})$ gene.

Differences between Egypt and other countries in antimicrobial usage could be contributed to differences in resistance gene profiles of CNS isolates originating from the same host species in different countries $[10,31,32]$. On account of mastitis-causing CNS, it is critical to identify resistant strains because such strains can serve as a store of resistance genes that can be exchanged to other bacteria posing additional difficulties to the control and cure of mastitis [7] and that could potentially pose a human health hazard [23].

From our previous results, it is clear that the rising incidence of resistance- encoding genes is usually related to long-term usage of tetracycline to treat various infections in the veterinary field as confirmed by Klimiene et al. [33].

A detailed phenotypic (42.8\%) and genotypic $(50 \%)$ tetracycline resistance analysis displayed associations of resistance/susceptibility phenotypes with potential resistance genes except in two isolates where an intermediate resistance phenotype (1/11, $9.09 \%$ ) harbored the tetK determinant and a susceptible phenotype $(1 / 11,9.09 \%)$ harbored the tet $\mathrm{K}$ determinant. This was in contrary to Cengiz et al. [34] who reported that phenotypically resistance tetracycline strains were more pervasive when contrasted with genotypically resistance strains in which only $33.3 \%$ out of the phenotypically resistance $S$. aureus strains demonstrates the presence of tetracycline $($ tet $\mathrm{K} /$ tet $\mathrm{M})$ resistance gene.

The multiple sequence alignment was done using different bioinformatics softwares, the results obtained showed high level of similarities (homology) between the local isolates sequences of tet $(\mathrm{k})$ and the reference sequences which retrieved from the GenBank databases including S. aureus strains, especially Egyptian (NCBI GenBank, http://www.ncbi. nlm.hih.gov/) except minor variations (Figure-3). This proves the possibility of transfer of the tetracycline resistance encoding genes between coagulase-negative and coagulase-positive Staphylococcus spp.

\section{Conclusion}

CNS isolates have distinguishingly high resistance rates to tetracycline. Abundant tetracycline usage for mastitis treatment leads to the spread of genetic resistance mechanisms inside CNS strains and among all Staphylococcus spp. Consequently, tetracycline is not effective anymore due to the high resistance rates in CNS isolated from buffalo cows with SCM or even clinically normal. Further, studies 
are needed to investigate the presence of other genes responsible for tetracycline resistance and this can be done using large number of samples and sequenced through the whole genome sequence to get complete picture on these genes.

\section{Authors' Contributions}

KAA conceived and designed the work performed the phylogenetic analysis and wrote the manuscript. AAA conducted the research work regarding the antibiotic resistance, molecular techniques, and the analysis and assisted in writing of the manuscript. Both RHH and ESI have assisted this research work regarding sampling, bacterial isolation, and identification. All authors read and approved the final manuscript.

\section{Acknowledgments}

Authors are grateful to Departments of Microbiology and Immunology and Department of Animal Reproduction, Veterinary Division, NRC for providing necessary research facilities to carry out various diagnostic tests. This study was funded by the authors.

\section{Competing Interests} interest.

The authors declare that they have no competing

\section{References}

1. Bogni, C., Odierno, L., Raspanti, C., Giraudo, J., Larriestra, A., Reinoso, E., Lasagno, M., Ferrari, M., Ducrós, E., Frigerio, C., Bettera, S., Pel-legrino, M., Frola, I., Dieser, S. and Vissio, C. (2011) War against mastitis: Current concepts on controlling bovine mastitis pathogens. In: Méndez-Vilas A, editor. Science against Microbial Pathogens: Communicating Current Research and Technological Advances. Zaragoza, Espãna: Formatex Research Center. p483-94.

2. Park, Y., Fox, L., Hancock, D., McMahan, W. and Park, Y. (2012) Prevalence and antibiotic resistance of mastitis pathogens isolated from dairy herds transitioning to organic management. J. Vet. Sci., 13: 103-105.

3. Supré, K., Haesebrouck, F., Zadoks, R.N., Vaneechoutte, M., Piepers, S. and de Vliegher, S. (2011) Some coagulase-negative Staphylococcus species affect udder health more than others. J. Dairy Sci., 94: 2329-2340.

4. Oliver, S.P., Gillespie, B.E., Headrick, S.J., Moorehead, H., Lunn, P., Dowlen, H.H., Johnson, D.L., Lamar, K.C., Chester, S.T. and Moseley, W.M. (2004) Efficacy of extended ceftiofur intramammary therapy for treatment of subclinical mastitis in lactating dairy cows. J. Dairy Sci., 87: 2393-2400.

5. Schwarz, S., Roberts, M.C., Werckenthin, C., Pang, Y. and Lange, C. (1998) Tetracycline resistance in Staphylococcus spp. From domestic animals. Vet. Microbiol., 63: 217-227.

6. Roberts, M.C. (1996) Tetracycline resistance determinants: Mechanisms of action, regulation of expression, genetic mobility, and distribution. FEMS Microbiol. Rev., 19: 1-24.

7. Irlinger, F. (2008) Safety assessment of dairy microorganisms: Coagulase-negative staphylococci. Int. J. Food Microbiol., 126: 302-310.

8. Osman, K.M., Abd El-Razik, K.A., Marie, H.S.H. and Arafa, A. (2016) Coagulase-negative Staphylococci collected from bovine milk: Species and antimicrobial gene diversity. J. Food Saf., 36: 89-99.
9. Thorberg, B.M., Kühn, I., Aarestrup, F.M., Brändström, B., Jonsson, P. and Danielsson-Tham, M.L. (2006) Pheno-and genotyping of Staphylococcus epidermidis isolated from bovine milk and human skin. Vet. Microbiol., 115: 163-172.

10. Sampimon, O.C., Barkema, H.W., Berends, I.M.G, Sol, J. and Lam, T.J.G. (2009) Prevalence and herd-level risk factors for intramammary infection with coagulase-negative staphylococci in Dutch dairy herds. Vet. Microbiol., 134: 37-44.

11. FAO/WHO/OIE. (2008) Joint FAO/WHO/OIE Expert Meeting on Critically Important Antimicrobials. Report of a Meeting Held in FAO, Rome, Italy, and WHO, Geneva, Switzerland, November. 26-30.

12. WHO. (2009) World health organization critically important antimicrobials for human medicine $2^{\text {nd }}$ Revision. WHO Advisory Group on Integrated Surveillance of Antimicrobial Resistance (AGISAR), Department of Food Safety and Zoonoses.

13. CLSI. (2012) Clinical and Laboratory Standards Institute: Performance Standards for Antimicrobial Susceptibility Testing. Twenty-Third Informational Supplement, CLSI, Wayne, PA.

14. Brakstad, O.G., Aasbakk, K. and Maeland, JA. (1992) Detection of Staphylococcus aureus by polymerase chain reaction amplification of the nuc gene. J. Clin. Microbiol., 30: 1654-1660.

15. Monday, S.R. and Bohach, G.A. (1999) Use of multiplex PCR to detect classical and newly described pyrogenic toxin genes in staphylococcal isolates. J. Clin. Microbiol., 37: 3411-3414

16. Duran, N., Ozer, B., Duran, G.G., Onlen, Y. and Demir, C. (2012) Antibiotic resistance genes and susceptibility patterns in staphylococci. Indian J. Med. Res., 135: 389-396.

17. Ng, L.K., Martin, I., Alfa, M. and Mulvey, M. (2001) Multiplex PCR for the detection of tetracycline resistant genes. Mol. Cell. Probes, 15: 209-215.

18. Felsenstein J. (1985) Phylogenies and the comparative method. Am. Nat., 125: 1-15.

19. Vanderhaeghen, W., Piepers, S., Leroy, F., van Coillie, E., Haesebrouck, F. and de Vliegher, S. (2014) Invited review: Effect, persistence, and virulence of coagulase negative Staphylococcus species associated with ruminant udder health. J. Dairy Sci., 97: 5275-5293.

20. Pyörälä, S. and Taponen, S. (2009) Coagulase-negative staphylococci-emerging mastitis pathogens. Vet. Microbiol., 134: 3-8.

21. Osman, K.M., Abd El-Razik, K.A., Marie, H.S.H. and Arafa, A. (2015) Relevance of biofilm formation and virulence of different species of coagulase-negative Staphylococci to public health. Eur. J. Clin. Microbiol. Infect. Dis., 34: 2009-2016.

22. El-Ashker, M., Gwida, M., Tomaso, H., Monecke, S., Ehricht, R., El-Gohary, F. and Hotzel, H. (2015) Staphylococci in cattle and buffaloes with mastitis in Dakahlia Governorate, Egypt. J. Dairy Sci., 98: 1-10.

23. Soares, L.C., Pereira, I.A., Pribul, B.R., Oliva, M.S., Coelho, S.M.O. and Souza, M.M.S. (2012) Antimicrobial resistance and detection of mecA and blaZ genes in coagulase-negative Staphylococcus isolated from bovine mastitis. Pesqui. Vet. Bras., 32: 692-696.

24. Booth, N. and Mcdonald, L.E. (1992) Farmacologiae Terapêticaem Veterinária. $6^{\text {th }}$ ed. Guanabara Koogan, Rio de Janeiro. p. 997.

25. Jamali, H., Paydarb, M., Radmehrc, B., Salmah, I. and Dadrasniaa, A. (2015) Prevalence and antimicrobial resistance of Staphylococcus aureus isolated from raw milk and dairy products. Food Control, 54: 383-388.

26. Zadoks, R. and Watts, J. (2009) Species identification of coagulase-negative Staphylococci: Genotyping is superior to phenotyping. Vet. Microbiol., 134: 20-28.

27. Levy, S.B., McMurray, L.M., Barbosa, T.M., Burdett, V., Courvalin, P. and Hillen, W. (1999) Nomen-clature for new 
tetracycline resistance determinants. Antimicrob. Agents Chemother., 43: 523-524.

28. Jamali, H., Radmehre, B. and Salmah, I. (2014) Short communication: Prevalence and antibiotic resistance of Staphylococcus aureus isolated from bovine clinical mastitis. J. Dairy Sci., 97: 2226-2230.

29. Walther, C. and Perreten, V. (2007) Methicillin-resistant Staphylococcus epidermidis in organic milk production. J. Dairy Sci., 90: 5351.

30. Thorberg, B.M., Danielsson-Tham, M.L., Emanuelson, U. and PerssonWaller, K. (2009) Bovine subclinical mastitis caused by different types of coagulase-negative Staphylococci. J. Dairy Sci., 92: 4962-4970.

31. Büttner, S., Flechtner, O., Müntener, C. and Overesch, G. (2011) Berichtüber den Vertrieb von Antibiotika in der Veterinärmedizin und das Antibiotika resistenz monitoring bei Nutztieren in der Schweiz(ARCH-VET 2010). Federal Veterinary Office and Swissmedic, Bern, Switzerland. Available from: http://www.swissmedic.ch/archvet-d.asp. Accessed on 26-12-2016.

32. Frey, Y., Rodriguez, J.P., Thomann, A., Schwendener, S. and Perreten, V. (2013) Genetic characterization of antimicrobial resistance in coagulase-negative staphylococci from bovine mastitis milk. J. Dairy Sci., 96: 2247-2257.

33. Klimiene, I., Virgailis, M., Pavilonis, A., Siugzdiniene, R., Mockeliunas, R. and Ruzauskas, M. (2016) Phenotypical and genotypical antimicrobial resistance of coagulase-negative Staphylococci isolated from cow mastitis. Pol. J. Vet. Sci., 19: 639-646.

34. Cengiz, S., Dinc, G. and Cengiz, M. (2015) Evaluation of antimicrobial resistance in Staphylococcus spp. Isolated from subclinical mastitis in cows. Pak. Vet. J., 35: 334-338.

$* * * * * * * *$ 